\title{
Nutritional Quality of Vegetable Pigeonpeas [Cajanus cajan (L.) Millsp.]: Dry Matter Accumulation, Carbohydrates and Proteins
}

\author{
U. SINGH, K. C. JAIN, R. JAMBUNATHAN, and D. G. FARIS
}

\section{-ABSTRACT}

Since average dry matter accumulation of green pigeonpea seeds intended for use as a vegetable was 65.6 of the total in matured seeds, green seeds were collected prior to physiological maturity. Green seed contained less starch and more dietary fiber than did mature seed. Flatulence causing oligosaccharides were present in a lower amount in green seed. Trypsin inhibitor activity (TIA) was more in mature seed whereas green and mature seed differed little in chymotrypsin inhibitor activity (CIA). The mean value for in vitro protein digestibility (IVPD) of green seed was more than that of mature seed. The green seed had a greater amount of tryptophan and threonine and the sulphur containing amino acids, methionine f and cystine. It is concluded that the green seeds of pigeonpea genotypes are mutritionally better than their mature secds.

\section{INTRODUCTION}

LI(;UME SEFDS are important for supplying protein to diets in many parts of the world. Pigeonpea |Cajanus cajan (L.) Millsp.] is a nutritionally important grain legume of tropical and sub-tropical regions of the world. While pigeonpea is predominantly consumed in the form of cooked dhal (decorticated dry split seeds) along with cereals, it remains a common practice in several countries to consume the developing green seeds shelled out of fresh pods. In India. developing green pigconpea seeds are used fresh as a vegetable in several states (Singh et al., 1977). The collection of pigeonpea pods is generally made 25-30 days after flowering. Large secded varieties are preferred for this purpose. The green pigeonpeas, mostly processed by canning and freezing, are consumed in some Caribbean and Latin American countries (Mansfield, 1980). Although reports are available on the methods of processing green pigeonpea seeds (Sanchez et al., 1961), limited information -is available on the nutritional quality of green seeds, particlarly for those cultivars used as a vegetable in India.

In legumes, there are two main aspects of protein quality (Boulter et al., 1976). First, the amino acid composition relative to the F.A.O. reference pattern (FAO/WHO, 1973) and second, digestibility and the presence of antimetabolic proteins (Liener, 1969). A large variation in protease inhibitors and in vitro protein digestibility of pigeonpea and its wild relatives has been reported earlier (Singh and Jambunathan, 1981a). Improvement of the nutritional quality of pigeonpea is one of the objectives at ICRISAT (Jain et al., 1980). Besides breeding for improved grain type, the development of pigeonpea cultivars suitable for vegetable use has been emphasized recently in an International Pigeonpea Workshop held at ICRISAT (Jain et al., 1980). We have examined the nutritional composition of green seed of pigeonpea for use as a vegetable. This paper reports the dry matter and nutritional quality of carbohydrates and proteins in green seeds and compares the results with those of the mature seed.

Authors Singh, Jain, Jambunathan, and Faris are affiliated with the International Crops Research Institute for the Semi-Arid Tropics (ICRISAT), Patancheru P.O., Andhra Pradesh 502 324, India.

\author{
MATERIALS \& METHODS
}

\section{Materials}

Nine pigeonera genotypes with a range of seed size (ICPl-11)2, ICPL-114, ICPL-119, ICPI-122, ICPI-128, ICPI-212, ICP-4)97 ICP.7035 and cv. (-11) grown in unreplicated plots were used for this study. These were grown on hlack soil at ICRISAl (enter. Patancheru, near Hyderabad during: the |98()-81 raing season. The crop was grown by using normal cultural practlecs. No irrigation or fertilizer was applied. The homopenous lots of pods contaming green seeds were collected at the stage when pigconpeas are perner ally harvested for use as a vegetable by growers. ciren seeds were shelled out of these peds manually. Mature seed samples of these same genotypes were collected. The fresh weight of the green seeds was recorded. The material was freeze-dried and moisture content determined. Dried green and mature seed samples were ground in a Udy cyclone mill using a $0.4 \mathrm{~mm}$ screen. After detatting in a Soxhles apparatus, using he ante, the material was used for chemical analyses.

\section{Methods of analysis}

Crucle fiber was determined aceurding, to the method of $\mathrm{AOAC}$ (1975). The procedure described by Van Socst and Wine (1973) was followed for the estimation of neutral detergent fiber. The analysis of dietary fiber as an estimate of unavailable carbollydrates was carried out according: to the method of Southgate at al. (1978).

Soluble sugars were extracted in a Soxhlet apparatus using $80 \%$ ethanol and estimated colorimetrically by the phenol-sulphuric acid method (Dubois et al., 1956). Thin-layer chromatography (TLC') was used to estimate glucose and fructose, sucrose, ralfinose. stachy ose and verbascose. ILC was carried out on a silica gel plate in the ascending fashion. The plates of 500 a thickness were prepared using a slurry of silica gel-(; in water and activated before use by heating it at $105^{\circ} \mathrm{C}$ for $35 \mathrm{~min}$. The solvent used consisted of chloroform:acetic acid:water $(6: 7: 1 \mathrm{v} / \mathrm{v})$. After separation, sugar spots wre detected on the TIC plates by spraying with aniline-diphenylalanine reagents. The TLC plates were scanned in a densitometer and sugar concentrations were calculated in comparison with sugar stan dards which were run simultaneously under identical conditions The following were the sources for the oligosaccharide standards: raffinose and stachyose (Sigma Chemical Co., USA) and verbascose (70\% pure, a gift from Nestlé Products. Technical Assistance Co., Ltd.. Switzerland) and other sugars of analar grade were used as standards.

Starch content in the dry residue, left after extraction of soluble sugar with $80 \%$ ethanol, was determined by exzymatic hydrolysis (Singh et al., 1980).

Amylase inhibitor activity. The inhibitor activity of pancreatic amylase (obtained from Sigma Chemical Co.. USA) was carried out according to the method of Jaffe et al. (1973). Amylase inhibitor was extracted by shaking a defatted sample with $0.02 \mathrm{M}$ phosphate buffer $\mathrm{pH} 6.9(1: 10 \mathrm{w} / \mathrm{v})$ for $2 \mathrm{hr}$ at room temperature. The suspen sion was then centrifuged at $10,000 \times g$ for $15 \mathrm{~min}$ at room temperature. The supernatant was then heated for $10 \mathrm{~min}$ at $70^{\circ} \mathrm{C}$, centrifuged again at $10,000 \times g$ for $15 \mathrm{~min}$ at room temperature, and the supernatant tested for amylase inhibitor activity.

Determination of in vitro digestibility of meal starch was determined using pancreatic amylase according to the procedure described by Singh et al. (1982). A suitable amount of defatted meal ( $50 \mathrm{mg})$ was dispersed in $1.0 \mathrm{ml}$ of $0.2 \mathrm{M}$ phosphate buffer, $\mathrm{pH}$ 6.9. Pancreatic amylase $(20 \mathrm{mg}$ ) was dissolved in $50 \mathrm{ml}$ of the same buffer and 0.5 $\mathrm{ml}$ was added to a sample suspension. Maltose was used as the standard and the values were expressed as $\mathrm{mg}$ of maltose released per $\mathrm{g}$ of sample.

Amino acid analysis. A suitable quantity of sample $(50 \mathrm{mg})$ was refluxed for $24 \mathrm{hr}$ in $50 \mathrm{ml} 6 \mathrm{~N} \mathrm{HCl}$. After evaporating the $\mathrm{HCl}$, the 
Table 1-Fresh and dry weight and moisture of green and mature seed of 9 pigeonpea cultivars

\begin{tabular}{|c|c|c|c|c|c|c|c|c|c|}
\hline Varieties & $\begin{array}{l}\text { Pod } \\
\text { color }\end{array}$ & $\begin{array}{c}\text { Seed } \\
\text { color } \\
\text { (mature) }\end{array}$ & $\begin{array}{l}\text { Fresh wt } \\
\text { (ing/seed) }\end{array}$ & 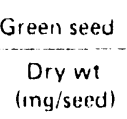 & $\begin{array}{l}\text { Moisture } \\
\text { ("u) }\end{array}$ & $\begin{array}{l}\text { Fresh wi } \\
\text { (my/seed) }\end{array}$ & $\begin{array}{c}\text { Mature seret } \\
\text { Drywi } \\
\text { (ing/seed) }\end{array}$ & $\begin{array}{c}\text { Morstuie } \\
\left(0_{0}^{\circ}\right)\end{array}$ & $\begin{array}{c}\text { Green seed as } \\
\text { " of mature } \\
\text { seed (dry wt } \\
\text { hasis) }\end{array}$ \\
\hline ICPL-102 & Mixed & Creain & 238.0 & 91.4 & 61.5 & 153.5 & 130.9 & 14.7 & 69.8 \\
\hline ICPL-114 & Mixed & Cream & 198.4 & 75.3 & 62.0 & 130.8 & 117.0 & 10.5 & 64.3 \\
\hline ICPL-119 & Mixed & Li brown & 216.2 & 80.8 & 62.6 & 146.4 & 129.4 & 11.6 & 62.4 \\
\hline ICPL-122 & Mixed & Lo brown & 200.6 & 82.1 & 59.1 & 143.4 & 129.0 & 10.0 & 63.4 \\
\hline ICPL-128 & Green & Brown & 226.7 & 86.4 & 61.8 & 140.8 & 123.8 & 121 & 69.8 \\
\hline ICPL.212 & Mixed & Cream & 206.9 & 90.4 & 56.4 & 144.6 & 126.0 & 12.2 & 71.7 \\
\hline ICP 6997 & Green & Brown & 208.4 & 78.9 & 62.1 & 142.5 & 125.7 & 119 & 626 \\
\hline ICP.7035 & Purple & Dk brown & 327.5 & 120.6 & 63.2 & 221.5 & 190.8 & 13.9 & 63.2 \\
\hline cv. C.11 & Mixed & Brown & 154.8 & 66.4 & 57.1 & 118.7 & 103.8 & 12.6 & 64.0 \\
\hline Mean & & & 198.6 & 85.8 & 60.7 & 149.1 & 130.7 & 12.2 & 65.6 \\
\hline
\end{tabular}

Table 2-Mean and range values of seed coat, fibers, starch, amylase inhibitors and in vitro starch digestibility of green and mature' seed of 9 pigeonpea cultivars

\begin{tabular}{|c|c|c|c|c|}
\hline Constituent & $\begin{array}{l}\text { Maturity } \\
\text { stage }\end{array}$ & Range & Mean & S.D \\
\hline Seed coat $(\%)$ & $\begin{array}{l}\text { Green } \\
\text { Mature }\end{array}$ & $\begin{array}{r}19.34-23.40 \\
9.03-16.70\end{array}$ & $\begin{array}{l}22.26 \\
13.57\end{array}$ & 0.54 \\
\hline Crude fiber $(\%)$ & $\begin{array}{l}\text { Green } \\
\text { Mature }\end{array}$ & $\begin{array}{l}7.93-8.67 \\
5.89-7.02\end{array}$ & $\begin{array}{l}8.19 \\
6.57\end{array}$ & 0.13 \\
\hline $\begin{array}{l}\text { Neutral-detergent } \\
\text { fiber }\end{array}$ & $\begin{array}{l}\text { Green } \\
\text { Mature }\end{array}$ & $\begin{array}{l}18.18-23.40 \\
13.50-18.74\end{array}$ & $\begin{array}{l}20.67 \\
16.56\end{array}$ & 0.74 \\
\hline Dietary fiber $(\%)$ & $\begin{array}{l}\text { Green } \\
\text { Mature }\end{array}$ & $\begin{array}{l}22.08-24.76 \\
17.92-21.60\end{array}$ & $\begin{array}{l}23.08 \\
20.11\end{array}$ & 0.60 \\
\hline Starch (\%) & $\begin{array}{l}\text { Green } \\
\text { Mature }\end{array}$ & $\begin{array}{l}46.60-50.99 \\
50.82-55.20\end{array}$ & $\begin{array}{l}48.39 \\
52.96\end{array}$ & 0.78 \\
\hline Amylase inhibitors ${ }^{a}$ & $\begin{array}{l}\text { Green } \\
\text { Mature }\end{array}$ & $\begin{array}{l}15.89-19.26 \\
22.51-34.15\end{array}$ & $\begin{array}{l}17.28 \\
26.87\end{array}$ & 1.25 \\
\hline $\begin{array}{l}\text { In vitro starch } \\
\text { digestibility }\end{array}$ & $\begin{array}{l}\text { Green } \\
\text { Mature }\end{array}$ & $\begin{array}{l}50.89-56.92 \\
32.43-40.10\end{array}$ & $\begin{array}{l}53.06 \\
36.22\end{array}$ & 0.93 \\
\hline
\end{tabular}

\section{a Units/g meal}

Expressed as $\mathrm{mg}$ maltose released/g meal

C Standard deviation of the difference

* Significant at $5 \%$ level

** Significant at $1 \%$ level

residue was dissolved in citrate buffer (pll 2.2). The amino acids were analyzed in a Beckman $120 \mathrm{C}$ amino acid analyzer. The mean coefficient of variability for the different amino acids ranged between 1.96 and $13.02 \%$ except for cystine where it was $22.12 \%$.

Determination of tryptophan was carried out colorimetrically according to Spies and Chambers (1949) with minor modifications as follows: a suitable amount of sample $(20-25 \mathrm{mg})$ was placed in a test tube which, after the addition of $10 \mathrm{~mJ}$ of solution of dimethylaminobenzaldehyde $\left(3 \mathrm{mg} / \mathrm{ml}\right.$ of $\left.19 \mathrm{~N} \mathrm{H}_{2} \mathrm{SO}_{4}\right)$, was incubated in the dark at room temperature $\left(25+2^{\circ} \mathrm{C}\right)$ for $18 \mathrm{hr}$. After incubation $0.1 \mathrm{ml}$ of $0.45 \%$ solution of sodium nitrite was added and the tube allowed to stand at room temperature for $30 \mathrm{~min}$ before reading the density at $590 \mathrm{~nm}$ in Spectronic-21 spectrophotometer.

Trypsin inhibitor activity. The trypsin inhibitor activity (TIA) was assayed according to Kakade et al. (1969). Trypsin inluibitor was extracted by shaking $200 \mathrm{mg}$ of defatted material with $10 \mathrm{~m}$ i of $0.1 \mathrm{M}$ phosphate buffer ( $\mathrm{pH} 7.6)$ at room temperature for $1 \mathrm{hr}$. The extract was diluted fourfold. Aliquots containing $0.2,0.4,0.6$ and $0.8 \mathrm{ml}$ were assayed for trypsin inhibitor activity. Protein content of the extract was determined according to Lowry et al. (1951).

Chymotry psin inhibitor activity. Chymotrypsin inhibitor activity (CIA) was assayed according to Kakade et al. (1970). Chymotry psin inhibitor was extracted as described above for trypsin except that $0.1 \mathrm{M}$ borate buffer at pH 7.6 was used. Protein content of the extract was determined according to Lowry et al. (1951).

In vitro protein digestibility. The determination of in vitro protein digestibility was carried out using pepsin and pancreatin enzymes (Sigma Chem. Co., USA) according to Singh and Jambunathan (1981b).
Polyphenolic compounds (polyphenols). Polyphenols were

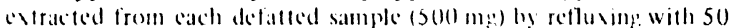
ml of methanol containing l: Hel for 4 hr. Ihe alrael was con. contrated in a rotary flash evaporator and brought to 25 mil with methanol HC 1 . The amount of phenolic compounds were estimated as tannic acid equivalent according: to the folin-Denis procedure (Swain and Ilillis, 1959).

\section{RESULTS \& DISCUSSION}

\section{Dry matter, fibers and starch contents}

The moisture content of green seed ranged from 50.4 $6.3 .2 \%$ indicating a small variation between the average of the samples (Table 1). Dry matter content of green seed varied from 75.3-120.6 mg/seed and of the mature seed from 117.0-190.8 mg/seed for these genotypes. The dry weight of the green and mature seeds of ev $(-1)$ was 66.4 and $103.8 \mathrm{mg} / \mathrm{sec}$, respectively. The dry matter accumulation of the green seeds was about $65 \%$ of the dry matter contained by the fully mature seeds (Table 1). This shows that the seeds were collected considerably before physiological maturity, which is the stage for maximum dry matter accumulation during seed development. This lack of physiological maturity was also revealed by the lower levels of starch in the green seed compared to that in the mature seed (Table 2). In a previous study, percent starch in the dehusked pigeonpea seed was maximum in samples collected at 28 days after flowering (Singh et al., 1980).

$A$ different trend between the green and mature seed indicated that the levels of crude-, neutral detergent-, and dietary-fiber in the developing seed were greater than in the mature seed. No clear differences between the large seeded pigeonpeas and the small-seeded one $((-11)$ were observed with respect to the levels of starch and various fibers (Table 2).

\section{Amylase inhibitors and in vitro starch digestibility (IVSD)}

Amylase inhibitors of green seeds were significantly lower than those of mature seeds (Table 2). Nutritionally, these inhibitors will be of little importance in countries where green seeds are consumed after cooking as amylase inhibitors become inactive when they are heated at $100^{\circ} \mathrm{C}$ (Hernandex and Jaffe, 1968). However, these inhibitors will be of considerable importance where fresh green seeds are consumed

IVSD, expressed as $\mathrm{mg}$ maltose released/g meal, ranged between 50.89 and 56.92 with the mean being 53.06 for these genotypes (Table 2 ). Significantly lower values for IVSD were obtained in the mature seed samples. The lower IVSD values of mature pigeonpea seed could be due to two factors: higher levels of amylase inhibitors in mature seeds, and a more complex starch-protein matrix as a result of seed maturation. The maturity of the seed has been reported 
to influence the susceptibility of starch to en/ymes in wheat (Kulp and Mattern. 1973). Further studies will be needed to accurately determine these relationships in pigeonpea.

\section{Soluble sugars}

The green seeds of pigeonpea contained more total solu. ble sugars than did mature seeds (Table 3 ). The relative concentration of reducing sugars and nonreducing sugars were significantly different in green and mature seeds. The percent soluble sugars was higher in green seeds than in mature seeds which agrees with the earlier results of Singh et al. (1980) who reported that percent soluble sugars increased in the early stages of seed development and then declined.

Using TLC it was found that glucose, fructose and sucrose were the predominant sugars of green seeds and that the concentration of these sugars declined as the seed matured (Table 3). (ilucose and fructose were estimated together as these sugars could not be resolved completely. A large variation was observed in the levels of glucose, fructose and sucrose in the green seed among the genotypes tested (Table 3). I('P-7035 contained the highest amount of glucose + fructose $\left(36.44^{\prime}\right)$ and the lowest amount of sucrose $(29.04 \%)$ in the developing seed. Such differences disappeared in the mature secd of this line. The variations observed in the levels of soluble sugars among vegetablepigeonpea cultivars and their importance to their consumer taste suggest that attempts should be made to select vegetable cultivars having a suitably high level of these sugars

Raffinose and stachyose were present in very low amounts in the green seed whereas they were detected in greater con centration in the mature seed (Table 3). Another oligosaccharide, verbascose, was not detected in the developing seed but was the predominant sugar in the mature seed. This clearly indicates that these oligosaccharides accumulate in the seed during the later stages of maturation. Food legumes are regarded as notorious inducers of flatulence when consumed in large quantities. In particular, the hydrogen component of intestinal gas is formed by the fermentation of low molecular weight galactosido-oligosaccharides-raffinose. stachyose and verbascose (Hellendoorn, 1969). The consumption of pigeonpea as a vegetable seems to be better than as a mature seed in view of the remarkably low amount

Table 3-Mean and range values of soluble sugars in green and mature seed of 9 pigeonpea cultivars

\begin{tabular}{|c|c|c|c|c|}
\hline Constituent & $\begin{array}{l}\text { Maturity } \\
\text { stage }\end{array}$ & Ranye & Mean & $S D^{\mathrm{b}}$ \\
\hline $\begin{array}{l}\text { Total soluble } \\
\text { sugars }(\%)\end{array}$ & $\begin{array}{l}\text { Green } \\
\text { Mature }\end{array}$ & $\begin{array}{l}4.70-5.54 \\
2.32-4.13\end{array}$ & $\begin{array}{l}5.09 \\
3.14\end{array}$ & $0.18^{*}$ \\
\hline Reducing sugars (\%) & $\begin{array}{l}\text { Green } \\
\text { Mature }\end{array}$ & $\begin{array}{l}1.24-2.06 \\
0.21-0.54\end{array}$ & $\begin{array}{l}1.59 \\
0.31\end{array}$ & $0.10^{* *}$ \\
\hline Non-reducing sugars (\%) & $\begin{array}{l}\text { Green } \\
\text { Mature }\end{array}$ & $\begin{array}{l}3.15-4.04 \\
2.11-3.59\end{array}$ & $\begin{array}{l}3.50 \\
2.83\end{array}$ & $0.15^{* *}$ \\
\hline Glucose + Fructose ${ }^{\mathrm{a}}$ & $\begin{array}{l}\text { Green } \\
\text { Mature }\end{array}$ & $\begin{array}{r}12.30-36.44 \\
0.84-3.90\end{array}$ & $\begin{array}{r}18.37 \\
2.11\end{array}$ & $2.55^{*}$ \\
\hline Sucrose $^{a}$ & $\begin{array}{l}\text { Green } \\
\text { Mature }\end{array}$ & $\begin{array}{l}29.04-65.72 \\
15.59-30.23\end{array}$ & $\begin{array}{l}52.60 \\
21.16\end{array}$ & $3.88 * n$ \\
\hline Raffinose $^{a}$ & $\begin{array}{l}\text { Green } \\
\text { Mature }\end{array}$ & $\begin{array}{r}1.25-9.50 \\
10.34-17.30\end{array}$ & $\begin{array}{r}6.19 \\
12.92\end{array}$ & $1.34^{* *}$ \\
\hline Stachyose & $\begin{array}{l}\text { Green } \\
\text { Mature }\end{array}$ & $\begin{array}{r}2.04-11.90 \\
12.29-19.40\end{array}$ & $\begin{array}{r}4.08 \\
15.72\end{array}$ & $1.19^{* *}$ \\
\hline Verbascose ${ }^{a}$ & $\begin{array}{l}\text { Green } \\
\text { Mature }\end{array}$ & $20.98-27.50$ & 24.89 & - \\
\hline
\end{tabular}

a Expressed as $9 / 100 \mathrm{~g}$ meal total soluble sugars

b tandard deviation of the difference

* Significant at $1 \%$ level of flatulence causing oligosaciharides in green sceds. Fur thermore, the variation in the levels of oligosaccharides in mature seed among pigeonpeat lines suggest that attempts should be made to sireen and then select cultivars with low amounts of these oligosacicharides.

\section{Protease inhibitors and in vitro protein digestibility (IVPD)}

While no large differences in the chymotrypsin unhibitut activity between green and mallure seed was observed. trypsin inhibitor detivity of mature secd was remarkably higher than that of the green seed ( lable 4 ). Ihis indicates an accumulation of trypsin inhibitors in mature seed. The in vitre protein digestibility of the green seed was more than that of the mature seed while a reverse trend was ob served for the polyphenolic compounds. This Indicated that polyphenolic compounds may have interfered with the in vitro protein digestability in these samples. Polyphenolic compounds showed a large variation among these genotypes ICP-70.35 had the highest amount of polyphenolic compounds in both green and mature seeds

Polyphenolic compounds are mostly present in the seed coat of grain legumes (Singh and Jambunathan. 198/b) and these compounds are known (1) inhibit the activity of degestive eneymes (ciritiths, l979, Singh, lost). In view of these observations the polyphenolic compounds have nutri tional implications as green pigeonpea seeds are normally consumed without decortication.

The nutritive value and protein digestibility of grain legumes are improved by processing or cooking as these treatments destroy the heat labile antimutritional factors (Bressani, 1972). Among these factors, trypsin and chymo trypsin inhibitors have been studied in detail (1 kener, 1979). Variation observed in the levels of protease inhibitors and IVPI) suggest that cultivars with a lower amount of such inhibitors which are associated with hetter protein digesti. bility should be selected in a breeding program.

\section{Amino acid composition}

The protein content of mature seeds was lower than those of green seed (lables 5 and (1) which might be due to an accumulation of starch during the later stages of maturation (Singh et al. . 1982). (onsiderable differences between green and mature seed were observed nutritionally as the levels of some essential and nonessential amino acids changed with maturation. On a dry weight basis, the green

Table 4-Mean and range values of protease inhibitors, in vitro protein digestibility and polyphenols of green and mature seeds of 9 pigeonpea cultivars

\begin{tabular}{|c|c|c|c|c|}
\hline Constituent & $\begin{array}{c}\text { Maturity } \\
\text { stage }\end{array}$ & Pange & Mean & $\mathrm{SD}^{\mathrm{d}}$ \\
\hline Trypsin inhibitor ${ }^{\mathbf{a}}$ & $\begin{array}{l}\text { Green } \\
\text { Mature }\end{array}$ & $\begin{array}{lr}2.40- & 3.86 \\
8.07- & 12.08\end{array}$ & $\begin{array}{l}2.80 \\
9.88\end{array}$ & $0.55^{\circ}$ \\
\hline Trypsin inhibitor $^{b}$ & $\begin{array}{l}\text { Green } \\
\text { Mature }\end{array}$ & $\begin{array}{l}26.44-45.44 \\
67.96-103.52\end{array}$ & $\begin{array}{l}32.97 \\
87.11\end{array}$ & $4.88^{*}$ \\
\hline Chymotrypsin inhibitor ${ }^{a}$ & $\begin{array}{l}\text { Green } \\
\text { Mature }\end{array}$ & $\begin{array}{ll}1.91- & 3.05 \\
2.07- & 3.63\end{array}$ & $\begin{array}{l}2.55 \\
2.96\end{array}$ & 0.19 \\
\hline Chymotrypsin inhibitor ${ }^{b}$ & $\begin{array}{l}\text { Green } \\
\text { Mature }\end{array}$ & $\begin{array}{l}12.75-22.15 \\
16.21-26.71\end{array}$ & $\begin{array}{l}18.16 \\
20.19\end{array}$ & 1.46 \\
\hline $\begin{array}{l}\text { In vitro protein } \\
\text { digestibility }^{c}\end{array}$ & $\begin{array}{l}\text { Green } \\
\text { Mature }\end{array}$ & $\begin{array}{l}63.89-72.09 \\
52.51-63.14\end{array}$ & $\begin{array}{l}66.80 \\
58.50\end{array}$ & $1.53^{*}$ \\
\hline Polyphenols $(\mathrm{mg} / \mathrm{g})$ & $\begin{array}{l}\text { Green } \\
\text { Mature }\end{array}$ & $\begin{array}{l}6.68-12.49 \\
6.05-18.34\end{array}$ & $\begin{array}{r}8.62 \\
10.60\end{array}$ & 1.10 \\
\hline
\end{tabular}

a Units intibited $/ \mathrm{mg}$ meal

b Units inhibited/mg extracted protein

c Percent digestible nitrogen

d Percent digestible nitrogen

- Significant at $5 \%$ level

* Significant at $1 \%$ leve 
Table 5-Amino acid composition (g/100g protein) of green seed of 4 pigeonpea cultivars

\begin{tabular}{lrr}
\hline Amino acid & ICPL-128 & ICP 6997 \\
\hline Lysine & 6.37 & 6.53 \\
Histidine & 4.22 & 5.31 \\
Arginine & 6.71 & 7.73 \\
Aspartic acid & 10.43 & 10.20 \\
Threonine & 3.94 & 4.01 \\
Serine & 4.97 & 4.53 \\
Glutamic acid & 17.29 & 18.21 \\
Proline & 4.13 & 5.06 \\
Glycine & 3.89 & 4.04 \\
Alanine & 5.46 & 5.20 \\
Cystine & 0.99 & 1.12 \\
Valine & 4.65 & 5.62 \\
Methionine & 1.42 & 1.65 \\
Isoleucine & 4.24 & 5.32 \\
Leucine & 7.48 & 9.15 \\
Tyrosine & 2.48 & 3.62 \\
Phenylalanine & 5.64 & 7.11 \\
Tryptophan & 0.91 & 0.90 \\
Total & 95.58 & 105.01 \\
Protein (\%) & 21.15 & 20.24 \\
\hline
\end{tabular}

\begin{tabular}{rr}
\hline ICP.7035 & C.11 \\
7.25 & 7.25 \\
4.41 & 5.59 \\
7.89 & 8.64 \\
11.71 & 10.05 \\
4.03 & 5.34 \\
5.50 & 4.91 \\
18.34 & 16.15 \\
5.07 & 4.41 \\
4.00 & 4.08 \\
5.06 & 4.11 \\
1.44 & 1.02 \\
4.92 & 6.21 \\
1.51 & 1.63 \\
4.18 & 5.38 \\
8.28 & 8.31 \\
3.25 & 3.21 \\
8.14 & 5.38 \\
0.73 & 1.10 \\
104.23 & 102.87 \\
21.26 & 21.30
\end{tabular}

seed contained a greater amount of the sulphur containing amino acids, methionine and cystine, tryptophan, threonine leucine and isoleucine than did the mature seed. The values for methionine and cystine reported here are probably low as these amino acids are partially destroyed during hydrolysis. Tyrosine and phenylalanine when considered together were considerably higher in the mature seed. Among the nonessential amino acids, proline, glycine and alanine werc higher in the green seed. This study shows that the protein quality, measured as a function of the level of essential amino acids, is better in the green seed than in the mature seed. Studies involving animal feeding experiments are required; however, to have a more precise idea of the protein nutritional quality of green and mature pigeonpea seed.

Although the overall effects of green pigeonpea consumption on its nutritive value should be studied, the nutritional composition of green seeds appeared to be superior to that of mature seeds when the results were expressed on a dry weight basis. Also, since there are differences among genotypes, these variations should be studied and utilized to develop pigeonpea cultivars suitable for use as a vegetable.

\section{REFERENCES}

AOAC. 1975. "Official Methods of Analysis." 12th ed. Association of Official Analytical Chemists, Washington, DC.

Boulter, D., Evans, I.M., and Thompson, A. 1976. Screening for protein quality in legumes. Qual. Plant. - Pl. Fds. IIum. Nutr. 26 : 107.

Bressani, R. 1972. Legumes in human diet and how they might be improved. In Nutritional improvement in food legumes by breeding. Proc. Sym. PAG/FAO, Rome, Italy, July, p. 15.

Dubois, M. Gilles, K.A. Hamilton, J,K Rebers, P.A and Smith, F 1956. Colorimetric method for determination of sugars and related 1956. Colorimetric method for deter

FAO/WHO 1973. Protein requirements. Report of a joint FAO/ FO/WHO 1973. Protein requirements. Report of a joint FAO/
WHO expert group. WHO Technical Rep Ser No 522, Geneva, WHO expert group
Switzerland, 0.63 .

Griffiths, D.W. 1979. The inhibition of digestive enzymes by extracts of field bean (Vicia faba). J. Sci. Food Agric. 30: 458 .

Hellendoorn, E.W. 1969. Intestinal effects following ingestion of beans. Food Technol. $28: 87$.

Hernandex, A. and Jaffe. W.G. 1968. Inhibitor de la amilasa pancreatica en caraotas (Phaseolus vulgaris). Acta Cient Venez. 19: 183.

Jaffe, W.G., Mareno, R., and Wallis, V. 1973. Amylase inhibitors in legume seeds. Nut. Rep. Int. 7: 169 .

Jain, K.C., Sharma, D., Gupta, S.C., Reddy, L.J., and Singh, U. 1980. Breeding for vegetable-ty pe pigeonpeas. In Proc. Int. Work-
Table 6-Amino acid composition (g/100g protem) of mature seed of 4 pigeonpea cultivars

$\begin{array}{lrrrr}\text { Amino acid } & \text { ICPL-128 } & \text { ICPL.6997 } & \text { ICP.7035 } & \text { C } 11 \\ \text { Lysine } & 6.90 & 6.25 & 6.73 & 6.95 \\ \text { Histidine } & 4.48 & 3.62 & 4.10 & 3.54 \\ \text { Arginine } & 7.24 & 5.58 & 5.66 & 6.88 \\ \text { Aspartic acid } & 10.34 & 9.13 & 8.91 & 9.16 \\ \text { Threonine } & 3.59 & 3.52 & 3.65 & 3.21 \\ \text { Serine } & 4.65 & 4.14 & 4.47 & 4.09 \\ \text { Glutamic acid } & 18.64 & 17.23 & 18.71 & 18.46 \\ \text { Proline } & 2.27 & 2.13 & 2.33 & 2.37 \\ \text { Glycine } & 2.78 & 2.77 & 2.88 & 3.11 \\ \text { Alanine } & 3.61 & 3.37 & 3.85 & 4.23 \\ \text { Cystine } & 0.90 & 0.80 & 1.19 & 0.77 \\ \text { Valine } & 4.03 & 3.07 & 3.78 & 3.92 \\ \text { Methionine } & 1.30 & 1.40 & 1.39 & 1.18 \\ \text { Isoleucine } & 3.23 & 3.13 & 3.14 & 3.34 \\ \text { Leucine } & 7.02 & 6.81 & 6.35 & 6.82 \\ \text { Tyrosine } & 3.03 & 2.60 & 2.94 & 2.64 \\ \text { Phenylalanine } & 9.22 & 9.19 & 9.54 & 8.18 \\ \text { Tryptophan } & 0.86 & 0.73 & 0.67 & 0.86 \\ \text { Total } & 98.08 & 95.07 & 90.29 & 88.71 \\ \text { Protein (\%) } & 19.24 & 18.34 & 17.63 & 20.03\end{array}$

shop on Pigeonpeus. ICRISAT, Patancheru, A.P., Indiu, Vol 2, p. 165 .

Kakade, M.L., Swenson, D.H., and Liener, I.E. 1969. An evaluation of natural vs synthetic substrates for meusuring the untitryptic activity of soybean samples. Cereal Chem. 46:518

Kulp, K. and Mattern, P.J. 1973. Properties of sturches derived from wheat of varied maturity. Cereal Chem. 50:496.

Liener, I.E. (Ed.) 1969 . "Toxic Constituents of Plant Food Stuffs." Academic Press, New York.

Liener, I.E. 1979. Protease inhibitors and Lectins. "International Review of Biochemistry, Biochemistry of Nutrition," Vol. 27, p. 97. (Ed.) A. Neuberger and T.H. Jukes, University Park Press. Baltimore, MD.

Lowry, O.H. Rosebrough, N., Farr, A.L., and Randall, R.J. 1951. Protein measurement with Folin.Phenol reagent. J. Biol. Chem. 193: 265 .

Mansfield, G.R. 1980. Processing and marketing of pigeonpeas: The case of the Dominican Republic. In "Proc. Int. Workshop on Pigeonpeas," Vol. 1, p. 344. ICRISAT, Patancheru, A.P., India.

Sanchez, N.F., Rodrigues, A.J., and Benero, J.R. 1961. Improved methods of canning pigeonpeas. University of Puerto Rico Arricultural Experiment Station Bull. 157. Mayaquez, Puerto Rico.

Singh, U. 1984. The jnhibition of dixestive enzymes by the poly. phenols of chickpea (Cicer arietinum L.) and pigeonpea (Cajanus cajan L.). Nutr. Rep. Int. 29:745.

Singh, U. and Jambunathan, R. 1981a. Protease inhibitors and in vitro protein digestibility of pigeonpea [Canjanus cajan (L.) Millsp.] and its wild relatives. J. Food Sci. Technol. 18:246.

Singh, U. and Jambunathan, R. $1981 \mathrm{~b}$. Studies on desi and kabuli chickpea (Cicer arietinum L.) cultivars: levels of protease inhibitors, levels of poly phenolic compounds and in vitro protein digestibility. J. Food Sci. 46: 1364.

Singh, U., Jambunathan, R., and Narayanan, A. 1980. Biochemical changes in developing seeds of pigeonpea (Cajanus cajan L.). Phytochemistry 19: 1291.

Singh, U., Kherdekar, M.S. and Jambunathan, R. 1982. Studies on desi and $k$ abuli chickpea (Cicer artetinum L.) cultivars. V. The levels of amylase inhibitors, levels of oligosaccharides and in vitro starch digestibility. J. Food Sct. 47: \$10.

Singh, L.. Singh, N., Shrivastava, M.P.. and Gupta, A.K. 1977. Characteristics and utilization of vegetable types of pigeonpeas [Cajanus cajan (L.) Millsp.]. Ind. J. Nutr. Diet. 14:8.

Southgate, D.A.T., Hudson, G.J., and Englyst, H. 1978. The analysis of dietary fiber - The choices for the analyst. J. Sci. Food Agric. $29: 279$.

Spies, J.R. and Chambers, D.C. 1948. Chemical determination of tryptophan in proteins. Anal. Chem. 21: 1249 .

Swain, T. and Hillis. W.E. 1959 . The phenolic constituents of Prumus domestica. 1. The qualitative analysis of phenolic conPrumus domestica. 1. The qualitative
stituents. J. Sci. Food Agric. 10:63.

Van Soest, F.J. and Wine, R.H. 1973. Use of detergents in the analysis of fibrous feeds. IV. The determination of plant cell wall constituents. J. Assoc. Official A nal. Chem. 50:50. Ms received $9 / 2 / 83 ;$ revised $12 / 19 / 83$; accepted $12 / 29 / 83$.

We thank M.S. Kherdekar, S. Gurtu, N. Subrahmanyam, and A.L. Reddy for their technical assistance in carrying out the analyses. Submitted as J. A. No. 341 by the International Crops Resesec Submitted as J. A. No. 341 by the Internation
Institute for the Semi-Arid Tropics (ICRISAT). 